\title{
PENGEMBANGAN MODUL BIOLOGI BERORIENTASI MODEL PROBLEM BASED LEARNING UNTUK MENINGKATKAN KOMPETENSI MAHASISWA
}

\author{
Lisa Fradisa ${ }^{1}$ \\ Lilisa Murni $^{2}$ \\ ${ }^{1,2,}$ STIKes Perintis Padang \\ E-mail: ${ }^{1}$ lisafradisa@gmail.com, ${ }^{2}$ lilisamurni64@yahoo.com
}

\begin{abstract}
The aims of this research is to produce a valid, effective and practical, Problem Based Learning Biological module to improve student learning competencies. The research method uses research and Development approach with 4-D model Thiagarajan. The resulting biological module tested its validity by biologists and learning media experts. For practical test conducted by lecturers and students while for effective test measured in three areas of competency namely cognitive, affective and psychomotor students who take biology course. The results of this study showed that the development of learning module-oriented biology of Problem Based Learning model has been valid, practical and effective to be used in biology lecture, especially in biology course for nursing.
\end{abstract}

Kata kunci: modul, problem based learning, kompetensi mahasiswa

\section{PENDAHULUAN}

Biologi menjadi salah satu mata kuliah wajib yang diambil mahasiswa strata satu keperawatan STIKes Perintis Padang yang masuk pada jalur ekstensi atau Program B. Materi dan konsepkonsep pembelajaran biologi berkaitan dengan gejala dan fenomena-fenomena yang terjadi dalam kehidupan sehari-hari (Hariatik dkk., 2017). Masih banyak mahasiswa yang belum mampu mengaitkan pengetahuan ilmiah yang di pelajari dengan fenomena yang terjadi di lingkungannya (Nuswowati dkk., 2017)

Dalam proses perkuliahan pengalaman belajar dan hasil belajar tidak hanya dapat meningkatkan hard skills akan tetapi peningkatan soft skills juga menjadi tujuan utama yang dibutuhkan mahasiswa terutama dalam memasuki dunia kerja (Delita dkk., 2016). Hasil belajar adalah suatu yang diperoleh individu atau kelompok setelah melakukan kegiatan belajar (Sepriyaningsih dkk., 2019). Pembelajaran tidak hanya bertujuan dalam meningkatkan hasil belajar pada ranah kognitif, tetapi harus sejajar dengan peningkatan kompetensi ranah psikomotor dan afektif. Peningkatan kompetensi mahasiswa merupakan salah satu cerminan terhadap peningkatan kualitas pembelajaran.

$$
\text { Peningkatan }
$$

kualitas pembelajaran terus dilakukan, diantaranya melalui pengembangan model pembelajaran, dan pengembangan bahan ajar yang inovatif, kreatif dan menarik. Pengembangan tersebut mampu memfasilitasi tercapainya kompetensi ranah pengetahuan, 
sikap, dan keterampilan berorientasi pendekatan berbasis keilmuan (Erinda dkk., 2018), yang dapat membantu mahasiswa mandiri dalam proses pembelajaran. Salah satu bahan ajar yang dapat menimbulkan kemandirian dalam belajar adalah modul. Ketersedian modul dapat membantu mahasiswa dalam memperoleh informasi tentang materi pembelajaran. (Nurhayati dkk., 2015) menjelaskan bahwa, modul merupakan paket belajar mandiri yang telah dilengkapi petunjuk untuk belajar sendiri sehingga pembaca dapat melakukan kegiatan pembelajaran tanpa kehadiran pengajar secara langsung. Namun demikian pengembangan modul harus disesuaikan dengan kebutuhan mahasiswa.

Berdasarkan hasil diskusi yang telah dilakukan peneliti sesama dosen pengampu mata kuliah biologi keperawatan di STIKes perintis Padang bahwa tidak adanya modul dalam pelaksanaan pembelajaran menyebabkan mahasiswa menjadi dominan mendengarkan dan mencatat yang sekaligus menjadi salah satu faktor pembelajaran yang tidak aktif melibatkan mahasiswa. Hal ini juga didukung dengan hasil diskusi yang dilakukan terhadap beberapa mahasiswa bahwa, dalam memperoleh informasi mahasiswa cenderung mengharapkan informasi dari dosen dan tidak menyenangi membaca buku yang berkaitan dengan materi biologi.

Terdapat berbagai potensi yang dapat dimanfaatkan untuk mengembangkan bahan ajar yang sesuai dengan kebutuhan mahasiswa, diantaranya dengan berorientasi pada model pembelajaran Problem Based Learning (PBL). Model PBL menuntut mahasiswa untuk menemukan sendiri pengetahuan mereka dimana permasalahan menjadi starting point dalam belajar (Rusman, 2010). Dengan demikian mahasiswa dilatih mengembangkan kemampuannya dalam memecahkan masalah.

Berdasarkan permasalahan di atas, maka telah dilakukan suatu penelitian dan pengembangan. Penelitian yang dilakukan adalah mengembangkan modul pembelajaran biologi berorientasi Problem Based Learning. Penelitian ini diharapkan dapat menghasilkan modul pembelajaran biologi berorientasi Problem Based Learning yang valid, praktis, dan efektif untuk mahasiswa keperawatan di STIKes Perintis Padang.

\section{METODE}

Model pengembangan yang digunakan dalam penelitian adalah model yang dikembangkan Thiagarajan berupa model 4D yang terdiri dari 4 tahap pengembangan yaitu Define, Design, Develop, dan Desseminate. Pengembangan modul pembelajaran biologi berorientasi Problem Based Learning hanya dilaksanakan sampai tahap pengembangan atau (develop). Modul yang dikembangkan dapat digunakan oleh dosen dan mahasiswa. Validasi modul oleh pakar atau ahli media pembelajaran, ahli materi. Data yang diperoleh dianalisis berdasarkan categorical judgments yang dimodifikasi dari Boslaugh (2008). Penilaian pakar terhadap masing-masing item pernyataan dianalisis menggunakan formula Kappa Cohen dimana pada akhir pengolahan diperoleh momen kappa.

$$
\text { moment kappa }(k)=\frac{P-P e}{1-P e}
$$

Keterangan: 


\begin{tabular}{|c|c|c|}
\hline $\mathrm{K}$ & $=$ & $\begin{array}{l}\text { moment kappa } \\
\text { menunjukkan validitas }\end{array}$ \\
\hline$P$ & $=$ & $\begin{array}{l}\text { Proporsi yang terealisasi, } \\
\text { dihitung dengan cara jumlah } \\
\text { nilai yang diberi oleh validator } \\
\text { dibagi jumlah nilai maksimal }\end{array}$ \\
\hline $\mathrm{Pe}$ & $=$ & $\begin{array}{l}\text { Proporsi yang tidak terealisasi, } \\
\text { dihitung dengan cara jumlah } \\
\text { nilai maksimal dikurangi } \\
\text { dengan jumlah nilai total yang } \\
\text { diberi validator dibagi jumlah } \\
\text { nilai maksimal }\end{array}$ \\
\hline
\end{tabular}

Hasil validasi digunakan sebagai pedoman revisi modul yang dikembangkan. Hasil revisi diujicobakan kepada mahasiswa dan dosen pengampu mata kuliah biologi keperawatan untuk melihat kepraktisan modul, menggunakan angket tertutup model skala Likert yang disusun berkategori positif berbentuk kontinum. Sedangkan keefektifan modul dilihat dari hasil tes hasil belajar ranah kognitif, afektif dan psikomotor sebagai bentuk penilaian kompetensi belajar mahasiswa.

\section{HASIL}

Hasil uji validitas produk oleh ahli media, ahli materi dan praktisi pendidikan menunjukkan kriteria valid dengan nilai momment kappa 0,84 dengan kategori sangat tinggi.

Uji kepraktisan modul dilakukan melalui pengisian angket oleh dosen dan mahasiswa STIKes Perintis Padang. Hasil uji kepraktisan modul oleh dosen menunjukkan bahwa produk yang dihasilkan termasuk dalam kategori sangat praktis dengan persentase ratarata $87,5 \%$. Hasil uji kepraktisan modul oleh mahasiswa menunjukkan bahwa produk yang dihasilkan termasuk dalam kategori sangat praktis dengan persentase $92 \%$.

Peningkatan kompetensi ranah kognitif didukur dari uji keefektifan produk berdasarkan nilai tes hasil belajar sedangkan peningkatan kompetensi ranah afektif dan psikomotor diukur dari uji keefektifan produk berdasarkan penilaian sikap dan keterampilan mahasiswa oleh observer selama proses pembelajaran menggunakan modul pembelajaran biologi berorientasi Problem Based Learning.

Uji kefektifan produk berdasarkan nilai tes hasil belajar menunjukkan bahwa produk memiliki keefektifan tinggi dalam meningkatkan kompetensi kognitif mahasiswa sebesar $16,84 \%$. Uji kefektifan kompetensi mahasiswa ranah afektif dan psikomotor menunjukkan bahwa produk yang dihasilkan dapat meningkatkan kompetensi sebesar 12,28\% dan 14,92\%

\section{PEMBAHASAN}

Pengembangan modul pembelajaran biologi berorientasi Problem Based Learning memuat tiga kegiatan belajar yaitu, membran plasma, sitoplasma dan komunikasi sel. Modul ini dirancang berdasarkan sintaks Problem Based Learning. Modul biologi berorientasi Problem Based Learning memfasilitasi mahasiswa belajar secara mandiri dan memiliki sikap-sikap ilmiah dalam penyelesaian masalah, seperti yang dinyatakan oleh Hariatik dkk., (2017), bahwa "Problem Based Learning dapat membantu peserta didik membangun kecakapan sepanjang hidupnya dalam memecahkan masalah, kerjasama tim dan berkomunikasi" hal ini sejalan dengan tuntutan kompetensi yang harus 
dimiliki mahasiswa pada akhir proses pembelajaran.

Pembelajaran mandiri menggunakan modul dilakukan oleh mahasiswa dalam memecahkan masalah yang disajikan pada bab pendahuluan dan membangun konsep-konsep dasar materi pembelajaran setelah membaca uraian materi yang disajikan modul, berdiskusi dan melakukan presentasi. Penyajian masalah pada modul disajikan pada bab pendahuluan bertujuan untuk memancing rasa ingin tahu, mengkritisi,dan berfikir unuk mencari solusi permasalahan sehingga nanti akan memperoleh pengetahuan awal dan pemahaman tentang materi yang akan dipelajari.

Penyajian materi sel pada pokok bahasan membran dan komunikasi sel dengan modul berorientasi Problem Based Learning ini dapat meningkatkan kompetensi, kemampuan memecahan masalah dan memberikan saran dan solusi sehingga menunjang peningkatan proses pembelajaran dan pencapaian tujuan pembelajaran secara optimal.

Validitas modul meliputi empat komponen. 1). Kelayakan teks yang terdiri dari penyajian materi, model pembelajaran yang digunakan serta soal evaluasi; 2). Kelayakan kontruks (komponen penyajian) terdiri dari sistematika penyusunan modul dan kemenarikan modul. 3). Komponen kebahasaan diukur dari tingkat kemudahan, keterpahaman pembaca. 4). Komponen kegrafisan diukur dari gambar, jenis huruf, tata letak, warna yang menarik minat baca mahasiswa. Berdasarkan komentar ahli media dan ahli materi menunjukkan bahwa modul yang dikembangkan layak digunakan dalam pembelajaran biologi (Riduwan, 2008).

Tingkat kepraktisan modul diukur berdasarkan kemudahan pemakaian modul dalam pembelajaran. Untuk mendapatkan modul pembelajaran yang praktis dilakukan pengujian praktikalits modul melalui angket respon dosen dan mahasiswa pada akhir pembelajaran setelah menggunakan modul yang dikembangkan. Hasil uji kepraktisan modul menunjukkan bahwa modul memiliki kriteria praktis karena dapat digunakan oleh mahasiswa secara mandiri dalam memahami materi pembelajaran dan juga bisa mengukur tingkat pemahaman materi melalui evaluasi yang terdapat di dalam modul.

Peningkatan kompetensi belajar mahasiswa sarjana keperawatan program B STIKes Perintis Padang diukur dari uji efektifitas modul. Tingginya kefektifan modul dalam meningkatkan kognitif mahasiswa memahami materi dan konsep dapat dipengaruhi oleh peningkatan kompetensi afektif dimana meningkatnya rasa ingin tahu, tingginya minat mempelajari materi secara mandiri, serta peningkatan kompetensi psikomotor melalui keterampilan mahasiswa dalam pemecahan masalah dan penyajian hasil diskusi sehingga memperoleh hasil belajar seperti apa yang diharapkan.

Sebelumnya mahasiswa belum menggunakan modul dalam pembelajaran, mereka belajar hanya menggunakan bahan power point yang diberikan oleh dosen, tanpa menggunakan bahan atau sumber belajar yang lainnya. Mahasiswa cendrung pasif dalam pembelajaran. Modul biologi berorientasi Problem Based Learning yang diberikan kepada mahasiswa 
mempengaruhi tingkat keefektifan, karena modul memiliki daya tarik untuk dibaca dan dipelajari sendiri di rumah, yang secara tidak langsung dapat memberikan kemudahan dalam pemahaman materi pembelajaran. Keefektifan modul ini juga dipengaruhi oleh keaktifan mahasiswa dalam melakukan diskusi dan presentasi kelompok. Hasil perolehan peningkatan kompetensi mahasiswa dalam pembelajaran biologi berkategori sangat baik dengan persentase peningkatan ratarata kompetensi cukup tinggi karena memperoleh pengalaman belajar aktif dan inovatif dalam proses pembelajaran seperti juga dalam praktikum (Asih dkk., 2018).

\section{KESIMPULAN}

Berdasarkan hasil dan pembahasan dari data penelitian yang diperoleh maka dapat disimpukan bahwa penelitian dan pengembangan ini telah menghasilkan perangkat pembelajaran berupa modul pembelajaran biologi berorientasi Problem Based Learning yang telah layak, praktis dan efektif digunakan dalam perkuliahan biologi, khususnya mata kuliah biologi untuk keperawatan.

\section{SARAN}

Modul pembelajaran biologi berorientasi Problem Based Learning yang dikembangkan ini telah dinyatakan valid dan praktis sehingga disarankan untuk dapat digunakan dalam perkuliahan khususnya biologi keperawatan.

\section{DAFTAR RUJUKAN}

Asih T, M. Khayuridlo, \& R. Noor. 2018. Pengembangan Modul
Praktikum Botani Tumbuhan

Rendah Melalui Identifikasi

Makroalga Kawasan Pesisir Barat

Lampung. Didaktika Jurnal

Penelitian Pendidikan Biologi. 2 (2), 93-102.

Delita, F., Elfayetti, \& T. Sidauruk, 2016. No Title Peningkatan soft skills dan hard skills mahasiswa melalui Project-based learning pada mata kuliah Perencanaan pembelajaran geografi. Jurnal Geografi, 8(2), 124-135.

Erinda, L., S. E. Indriwati, \& E. S. Sulasmi. 2018. Pengembangan Modul Keanekaragaman Tumbuhan Home Science Process Skill Berbasis Inkuiri Terbimbing Bermuatan Karakter Untuk Meningkatkan Hasil Belajar Dan Keterampilan Proses di MAN 1 MalangPengembangan Modul Keanekaragaman Tumbuhan Home Science Process Sk. Jurnal Pendidikan Biologi, 9(2), 64-70.

Hariatik, Suciati, \& Sugiyarto. 2017. Pembelajaran Biologi Model Problem Based Learning (PBL) disertai Dialog Socrates (DS) Terhadap Hasil Belajar ditinjau dari Kemampuan Memecahkan Masalah Kelas X. Jurnal Pendidikan Biologi, 8(2), 45-51.

Nurhayati, D. F.Saputri, \& I. N. Sari. 2015. Efektivitas penggunaan modul fisika berbasis inkuiri terhadap hasil belajar dan kemandirian belajar mahasiswa 1,2,3. Jurnal Pendidikan Informatika Dan Sains, 4(2), 247258.

Nuswowati, M., E. Susilaningsih, Ramlawati, \& S. Kadarwati. 2017. Implementation of problem-based 
learning with green chemistry vision to improve creative thinking skill and students' creative actions. Jurnal Pendidikan IPA Indonesia, 6(2), 221-228.

Riduwan. (2008). Variabel-variabel Penelitian. Bandung: Alfabeta.

Rusman. 2010. Model-model Pembelajaran (Mengembangkan Profesionalisme Guru Edisi Kedua) (Kedua). Jakarta: Raja Grafindo Persada.

Sepriyaningsih, D. Samitra, \& M. Yunita. 2019. Pengaruh Model Team Assisted Individualization (TAI) Terhadap Hasil Belajar Biologi Siswa Kelas X SMA Negeri 8 Lubuk Linggau Pendidikan Biologi, STKIP PGRI Lubuklinggau. Jurnal Pendidikan Biologi, 4 (1), 29-34. 